I should say, gratuitous falsehoods-but, on the contrary, as a deliberate scheme on the part of the author for safe-guarding himself against a by no means impossible vengeance. And I would print it, as it appears in most editions, in the fore-front of the book, as having a special relation to the First and Fourth Satires.

Alfred Pretor.

\title{
NOTES
}

W Iтн reference to Mr. Jones' interesting paper on the influence of the PseudoPlutarchean treatise $\pi \epsilon \rho \grave{i} \pi a \hat{i} \delta \omega \nu$ a $\gamma \omega \gamma \hat{\gamma} s$ on the Humanists, it is a noteworthy fact that there exists in numerous MSS. dating from the fifteenth to the eighteenth century a recensio of this treatise, containing a considerable number of interpolated corrections of the text as we find it in the genuine tradition of Plutarch's Ethica. Ducas in editing the treatise for the Aldine took this recensio as a basis, and it is, in consequence, the base of our present editions of the text. I have not of course seen all these late MSS. of the treatise, but I find that all those in Paris, four in number, correspond to the Aldine text in the passages I have compared; so it is highly probable that the others reproduce this recensio. The changes, I should say, are of no great importance for the context, the interpolations in question being only corrections making certain corrupt passages readable. The interesting fact is the continued reproduction in manuscript form of this treatise in the East up to the eighteenth century, showing that it was regarded as a classical manual on the principles of Education. It must have been so regarded in the East at the date of the earliest of these MSS. (fifteenth century), and, I think, earlier; so that it had already earned this reputation in the East when it fell into the hands of the Western Humanists.

As we cannot trace the tradition of the Ethica of Plutarch beyond the twelfth century, we do not know at what date this selection from his works (the first 2 I treatises of the Planudean Corpus of the Moralia, separately preserved in the same order in many MSS.) was made. The treatise there occupies a place of honour, the second, and it must at that time have been in great repute in order to earn this place. Its reputation must go still further back, and possibly traces of it may be found in earlier Byzantine literature.

As to its authorship, it is significant that Wyttenbach quotes many parallels to its diction from Philo. I do not mean to suggest that it is by Philo.

\section{W. R. Paton.}

\section{OBITUARY}

\section{FRIEDRICH BLASS.}

By the death of Friedrich Blass on March

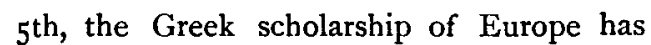
lost one of its foremost representatives. Born at Osnabrück in January, 1843, and educated at the local gymnasium under B. $\mathrm{R}$. Abeken (the author of Cicero in seinen Briefen), he studied at Göttingen under Sauppe, and at Bonn under Ritschl and
Otto Jahn. After holding scholastic appointments in various parts of Germany, he was appointed to a professorship at Kiel, and promoted in 1892 to a similar position at Halle, which he filled with the highest distinction for the remaining fifteen years of his life.

His dissertation on the rhetorical works 
of Dionysius of Halicarnassus, written for his degree at Bonn in 1863 , was the germ of his earliest substantial work, that on the history of Greek oratory from the age of Alexander to that of Augustus (1865). This was followed by the greatest of his works, the four volumes of Die Attische Beredsamkeit (1868-80), which attained a second edition in 1887-98. For the Teubner series he edited the texts of all the Attic Orators except Lysias and Isaeus; repeatedly revised Rehdantz' Philippics, and produced a school edition of the De Corona, and of eight of Plutarch's Lives. His critical texts of the

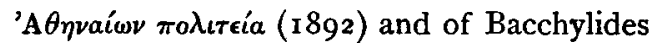
(I898) have passed through several editions. His treatise on Greek pronunciation and his Grammar of New Testament Greek were translated into English; he also produced a thoroughly revised edition of the first half of Kühner's Greek Grammar, besides writing on the 'Philology of the Gospels,' and the 'Criticism of the New Testament,' and dealing with the texts of St. Luke and St. John, the Acts of the Apostles, and the Epistle to the Hebrews. In the interval between his two works on the Rhythm of Greek Prose. (190I and 1905), he produced his treatise on Interpolations in the Odyssey (I904). His latest work was a commentary on the Choëphoroe (1906).

His published works frequently brought him into friendly relations with scholars in this country. In 1879 he was the guest of the editor of the editio princeps of Hypereides, Churchill Babington, and in the same year he stayed in Cambridge with the present writer. In 1892 he received an honorary degree at Dublin, and delivered a brief Latin address, which is published in the Tercentenary Records (p. 257). At the Bicentenary of Halle he entertained Prof. Mahaffy and myself, as delegates from our respective Universities. On his last visit to Cambridge he for the first time made the personal acquaintance of Sir Richard Jebb. In London, Oxford, and Dublin, he repeatedly gave proof of his remarkable skill in deciphering and identifying the fragments of Greek papyri and in restoring the lacunae in the

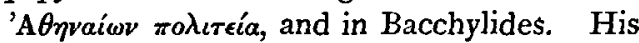
summer vacations were usually spent in the Harz and the Riesengebirge, and he also visited Greece and Italy and Sicily. Those who knew him best recognised in him 'a character of rare simplicity and goodness,' and of unaffected piety. He was a man of a large heart and of a calm and sober temper ; and he was ever ready, with an absolute unselfishness, to place the results of his learning and of his acumen at the service of others. The expression of his face may perhaps be described as earnest and resolute, but not unkindly; while the beauty of his character will prompt his friends in this

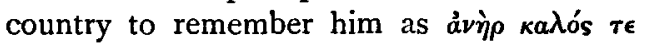

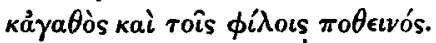

J. E. Sandys.

\section{NEWS AND COMMENTS}

As a specimen of the buffoonery in which reviewers (or editors) think fit to indulge, when attacking the reformed pronunciation of Latin, we quote the following morsel of humour from a notice of a recent pamphlet in Education (March 15, 1907) :-

\footnotetext{
"We confess to an "inwinkible" objection to the proposed change, which adds new terrors to the study of the classics. Our main objection is that it would render it almost impossible to the average Englishman to trace the connexion of the multitude of words in our language which are derived from the Latin. Again, the efforts of the reformers seem to
}

be directed to getting rid of the British " $I$ " sound. The sound of " $I$ " as in "bite," is the mark of a dominant and powerful race like our own and the mighty men of ancient Rome. We are convinced that the Roman, at his best, pronounced his $I$ as $I$, and not as a soft $\mathrm{E}$. We have very vivid recollections of an attempt of our classical form master(alas! some thirty years ago)-to introduce the new or reformed pronunciation into the class. It came to an abrupt conclusion when the boys were required to apply the new pronunciation to the word-causas!'

Education circulates amongst the members of County Councils and Town Councils, and elementary schoolmasters. 